\title{
Implementing Learner-Centered Approach to Teaching Science in Higher Education
}

\author{
Iman Mesfar Alqahtani ${ }^{1}$ \\ ${ }^{1}$ Departement of Curriculum and Teaching Methods, College of Science and Humanity Studies, Imam Abdulrahman \\ bin Faisal University, Saudi Arabia \\ Correspondence: Iman Mesfar Alqahtani, Lecturer, Departement of Curriculum and Teaching Methods, College of \\ Science and Humanity Studies, Imam Abdulrahman bin Faisal University, Saudi Arabia.
}

Received: May 13, 2020

doi:10.5430/irhe.v5n2p45
Accepted: June 13, 2020

Online Published: July 11, 2020

URL: https://doi.org/10.5430/irhe.v5n2p45

\begin{abstract}
This study was to examine the effectiveness of student-centered approach to teaching science in higher education on students' performance, students' motivation and students' social skills. The population in this study was 22 students who were admitted to the single subject credential program. The participants registered in Methods and Materials in Middle School Science Teaching (CI 161). Students' science achievement was measured by using the pre-test and a post-test achievement test that created by this researcher based on expectancy and goals of the course. Also, this research used two questionnaires were conducted at the end of the academic semester to measure students' motivation towards science learning and the second one to measure the influence of this approach on students' social skills. The result was implementing student-centered approach to teaching science in higher education has positive influences on students' performance, students' motivation and students' social skills.
\end{abstract}

Keywords: learner-centered, performance, motivation, social skills, science, higher education

\section{Introduction}

In recent years, a number of major changes have occurred in the educational system; some of them are positive, and some are negative based on research and studies. One of the modifications is the change in the entire spectrum of teaching methods, such as teacher-centered approach to student-centered approach to teaching science in higher education. This has caused a heated debate among educators and teachers about the effects of these approaches in the performance, motivation of students, and their social skills. In order to realize the positive effects of student-centered approach to teaching science, this research will clarify a brief explanation of each method

First of all, in the teacher-centered approach, teachers usually use the lecture method, and they do not focus on what the students are learning from their lecture. This assurance on what teachers do often leads to students who are passive students. In addition, the students in this approach do not take responsibility for their own learning. Educationalists label this traditional method "instructor-centered teaching." In contrast, "learner-centered teaching" happens when instructors focus on student learning.

More teachers have moved toward a student-centered approach. In addition, student-centered teaching is an approach to teaching that is progressively being applied and encouraged to apply in higher education. Learner-centered teachers do not employ a single teaching method. This approach emphasizes a variety of different types of methods that shifts the role of the teachers from givers of information to facilitators of student learning.

According to the article" Learner-Centered Teaching: Five Key Changes to Practice", Weimar (2016) said Zophy in his research explained about how difficult it has been to make it possible to move learning from a teacher- centered style where students just listen at times as passive learners to learner-centered where students are actively involved in the learning process. Discussions about this change have been characterized as full of chaos at times. There has been an effort in the recent years to encourage the learner- centered approach because it gives students a chance to be involved and they learn a lot as compared to when they just listen without contributing actively to the learning process.

Over the years, several theories have been brought forward to explain the best way in which learners can be able to learn and, at the same time, benefit from the process. Weimar in her theory insisted in a situation where the role of 
the teacher becomes limited, and the students become more actively involved in the process. This idea has been realistic as compared to what Zophy was advocating. However, the situation has not changed significantly but has just remained to be teacher centered whereby the students depend primarily on the teacher's knowledge rather as opposed to having the teacher as a facilitator of the learning.

The learner-centered approach is interesting in several aspects. First of all, it gives the students a challenge and they find the solutions to such problems. In other words, student-centered approach to teaching science helps students to think critically in order to learn and achieve the lecture's objectives. In addition, active involvement in the learning process makes learning interesting and easy. Most students are considered to understand well when they are the ones doing the learning and trying to solve the problems themselves. This learning method has been found to be more efficient for most students, because most students cannot concentrate fully when they only get content from the teacher without being involved in the learning actively.

In addition, this step has for several years given a dilemma to most scholars especially considering the quality and also the risks that may arise from giving students a lot of power to control their learning. Some educators center the argument on the fact that university level studies are not only student-centered to teaching science but also it is about expertise in a certain field.

Furthermore, the learner-centered approach also gives the students an opportunity to exercise independence when making decisions as opposed to when the teacher is the sole decision maker in the learning process. The exercise of freedom makes students more innovative in that their decisions are not limited to a certain point in the learning process. Also, it plays a key role to raise students' academic performance. For college and university students, this aspect is of great importance since they can come up with ideas, try them practically, and make adjustments. By doing this, they end up coming up with better innovations and performance. Students who are not given a chance to be independent at times fail to explore ideas since they only get instructions from the teacher. Also, sometimes it affects students' performance negatively.

Initial thoughts on the best way to study this type of teaching were that learning contents were not of importance but according to Weimar coverage of material was not learning but an understanding of the content is what is important in the learning process. Students, therefore, in any case, are responsible for making learning a reality because a teacher can only cover content, but it is for the students to learn. Teachers who mostly use the student-centered approach to teaching sciences make it easy for students to learn and understand because in most cases they give instructions that help students to remember what they learn for a longer period.

The research method for this project was a non-experimental design. The causal-comparative research that this research pursued to identify associations among variables and attempted to determine the effects of using student-centered approach versus teacher-centered approach to teaching science on students' performance and motivation among groups of students.

In term of the benefits of this research that might have for my work as an a teacher assistant the department of education "Curriculum and instruction" at Dammam University in Saudi Arabia, hoping this research will be well-shifted action that improves the teaching approaches of science and contributes to enhancing students' achievement in higher education. Furthermore, hoping also that research plays a key role to help any educators to design and plan curriculum based on students' needs and interests. In addition, this paper will give the reader a clear picture of the tasks for the learner and the teacher in learner-centered approaches.

In addition, this learning strategy gives teachers the overview of how best teachers can deliver their teaching in the most efficient manner that will allow their students to grow and also give me the satisfaction of my job. A teacher will always feel satisfied when his or her students are getting the content of the coverage and can be able to put it into practical form. Every student will be able to productive in that when their abilities are explored thoroughly they end up been of benefit to both the student and the society. This will be done by learning the weakness and strengths of each student thus as a tutor it will be easy to handle each one of them efficiently. Students will, therefore, be in a position to feel productive in their studies and more specifically being that they become expertise in their field of study.

The aim of this research was to find out answers for the questions that will be included in my research: the benefits of learner-centered approach to teaching science in higher education; the impact that a teacher has in the learner-centered method; how does student-centered approach impact on the performance of a student; how does learner-centered approach influence the motivation of a student; and how does student-centered approach impact on the social skills of a student? 


\section{Review of the Literuture}

In the recent past, there have been numerous transformations with regards to the educational system. One key change has been that of the whole spectrum of teaching techniques such as teacher-centered approach to student-centered approach to teaching science in higher education (Ernst \& Ernst, 2005). This particular transformation has resulted in a heated discussion among teachers and educational professors in higher education about the influence of these approaches on the performance, motivation, and social skills of learners. In order to show studies and research papers that indicate the positive effects of the student-centered approach to teaching science in higher education on students' performance, students' motivation, and students' social skills, this researcher will offer a brief explanation of each method.

Sharkey and Weimar (2016) said in teacher-centered approach teachers usually use the lecture method, and they do not focus on what the students are learning from their lecture. This assurance on what teachers do often leads to students who are passive students. In addition, the students in this approach do not take responsibility for their own learning. Educationalists label this traditional method, "instructor-centered teaching." In contrast, "learner-centered teaching" happens when instructors focus on student learning.

Student-centered teaching is an approach to teaching that is progressively being applied and encouraged to apply in higher education. Weimar (2016) said more teachers have moved toward a student-centered approach. In addition, learner-centered teachers do not employ a single teaching method. This approach emphasizes a variety of different types of methods that shifts the role of the teachers from givers of information to facilitators of student learning.

What Is Currently Known About The Problem Of Practice?

Over the past years, there have been numerous attempts to implement student-centered approaches particularly in science classrooms. One student-centered program that has so far encouraged student inquiry is the Biology Guided Inquiry Learning Environments or the BGuILE (Brown, 2008). Here, learners are presented with new issues to investigate where they decide what information to gather and what procedures to adhere to. Learners are also given the chance to construct their own clarifications for what they see. Although learners make progress in making their discourse more scientific, the way of discussing what they have seen in the science classroom does not come easily and teachers are forced to intervene. This has in turn created a tension between a prearranged manner of conducting something and the learners' more natural day-to-day manner of doing it. It raises questions about what it means to make use of a student-centered approach. All this has been attributed to the outcome of expectations imposed by the Ministry of Education, educational institutions, and teachers in the form of content principles representing an organization of presently accepted theories and ideas in science (Lord, 2001). Unfortunately, this is not the only thing limiting the implementation of student-centered learning in school classrooms. Some learners do not actually find exploring the physical world fundamentally rewarding, and do not possess the maturity to perform either autonomously or in small groups. The main concern is how benchmarks, high stakes standardized assessments, and standards establish a surrounding that makes student-centered learning harder while challenging some of its significant principles.

In the recent past, educators and science teachers have shown concern in the way science is being taught, and a number of national efforts have been concentrated on redesigning the instruction of precollege science subjects. The main issue is that conventional science teaching has relied on frequent memorization of long sets of certain vocabulary and lecturing facts (Brown, 2008). The outcomes of such teaching have been in limited learning reflected on poor content retention, lack of student interest for the sciences, inability to apply ideas, and limited scientific skills. When educational experts began taking a closer look at college instruction, they discovered that similar conventional teaching model was adhered to throughout the universities. They also identified grave ramifications on the quality of science education attained by college students. Despite the fact that student-centered approach to teaching science assists learners to think critically so as to achieve and learn the lecture's goals, this particular step has given dilemma to numerous scholars. Some educators argue that the university level studies are not only student-centered to teaching science, but are also about expertise in a particular area (Blumberg, 2009).

Following the onset of technological advancements, modern day technology was very much embraced by learners, particularly those learning speed proficiencies due to the establishment of a learning-centered learning experience. Nonetheless, this overwhelmed and frustrated the instructors in need of pedagogical orientations. The instructors were also overwhelmed with the duties of how to incorporate this modern day expertise that fell solely on their shoulders. Without appropriate sustenance from pedagogically firm curriculum structures, learner-focused teaching is far from being utilized regularly. Notably, conventional techniques tend to a diminished ability to achieve the objective of providing immediate image feedback. Normal process depends on the teacher's vocal account on the 
related error (Blumberg, 2009). Such an effort also depends on the supposition that student's fuzzy recollection on past presentations could be brought to mind precisely. Even though high-end technology provides learner-focused feedback to employ learners in learning, each step requires far-reaching teacher input of energy and time so as to make the most of student-centered learning.

After looking at what is currently known about the problem of practice, this section illustrates the positive influences of implementing learner-centered method to teaching science. Over the past several years, the student-centered approach to teaching science has been increasing. One group of people thinks that student-centered approach is more effective than traditional teaching such as teacher-centered approach. Also student-centered approach affects the educational society in several aspects such as students' academic achievement, students' motivation, and students' social skills.

\section{Student-Centered Affects Students' Performance}

Slunt and Giancarlo (2004) said the system of education and teaching has been designed to implement teaching techniques such as student-centered and distinctive approaches where the lecture is the main ways of dispensing information to learners. Many educational institutions around the world tend to stick to this particular structure of teaching because of specific policies, and its various positive influences on a learner's academic performance.

In addition, despite the concept of student-centered learning approaches, the idea of teacher-as-facilitator has increasingly become synonymously linked to student-centered learning. It is argued that teachers should operate as facilitators of learning, moving from being the "sages on stage to guides on the side" (McFarlane, 2010). If today's educational society is to rightfully encourage educators to adopt and progress student-centered approaches that incorporate less interference and direction from teachers, then a greater comprehension of the duty of teachers in student-centered surroundings is needed. Notably, the student-centered approach provides students with a chance to exercise autonomy when making decisions compared to when teachers are the sole decision makers in the learning process. This exercise of liberty makes students become more innovative in the sense that their decisions are not restricted to a specific point in the process of learning. From what has so far been observed, learners who are not provided with an opportunity to be independent tend to fail in exploring notions since they only obtain instructions from their educators. As a result, the student's performance is negatively affected (Slunt \& Giancarlo, 2004).

In addition, Akınoğlu and Tandoğan (2007) studied the effects of student-centered approach to teaching science in higher education on students' academic achievement and students' concepts. They conducted their study in a public school in Istanbul. There were 50 students participated in the 2004-2005 academic year. Teachers taught science class by implementing student-centered approach. In addition, the researchers used quantitative and qualitative research methods to find the effects. They collected the quantitative data through pre/post-tests, and treatment-control groups test model and the qualitative data were obtained through document analysis. After 30 classes hours, the results of implementation of problem-based had positively affected students' academic achievement and their attitudes towards the science course. In addition, it affects students' concept positively.

In order to increase students' performance, Kennedy (2009) said some authoritative educators have realized the significance of being globally competitive by making use of today's teaching techniques. Some of the methods that have so far been implemented in an effort to improve students' academic performance include cooperative and student-centered strategies. Student-centered strategy refers to a social technique that usually engages learners in energetic, rather than passive learning.

In addition, Davis (2015) described the effects of applying student-centered approach on Pre-calculus courses for two-semester-long. At the beginning of the study the researcher described the teaching approaches, which included a mixture of lectures, student presentations, group work, discussion, and guided investigations. Students were taught with either the instructor-centered teaching methods, or with the collaborative learner-centered approaches. The result was the average over all students were higher on quizzes when they were taught with leaner-centered methods. Davis suggested that not only are student-centered approaches more effective than teacher-centered approaches, but that they are particularly helpful to those students who are struggling with Pre-calculus. So this study shows how the student-centered approach plays a key role in increasing students' performance.

\section{Student-Centered Affects Students' Motivation}

Student-centered plays an important role in affecting students' motivation positively. Ivey (2011) showed the positive effects of student-centered method on students' motivation in his study " Opening up the conversation on literacy, college, and career". Ivey said that student-centered learning and teaching is believed to be consistent with the view of Piaget (1963) who suggested that learners tend to develop personal meaning about the physical world 
through conversation and direct experience with others about similar experiences. People who support student-centered teaching do so on the foundation of a wide range of arguments; for instance, the fact that learners should have the right to choose what is most appropriate and interesting since prearranged knowledge is quite meaningless to them. Additionally, they also believe that when extrinsic motivators are utilized to interest learners in the curriculum, students lose interest after such motivators are eliminated.

While motivation is considered to be both a precondition for and subject of self-regulation, it is important to focus on the element of motivation due to its centrality in illuminating learning and attainment behavior. Situational interest that brings about participation with specific field content may result in personal interest which is the reliable and stable interaction with the field. There have been many other attempts in the past to implement student-centered approaches particularly in science classrooms. However, one of the most interesting has been inquiry teaching, also referred to as problem-solving, project-based teaching, guided discovery, discovery learning, and inductive teaching (Painter, 2009). This is founded on the premise that learners could be scientific inquirers in the classroom, generating meaning more independently or with less of the educator. These inquiries would educate them on both the notions and methods of science.

Notably, another approach to student-centered learning incorporates the use of engineering design assignments to encourage scientific inquiry. This is founded on the assumption that real life practical issues are more authentic to learners and thus more motivating (Yuzhi, 2003). In 1998, a science teacher in Germany discussed an experiment in student-centered learning that he carried out at an integrative all-inclusive school. Here, students were studying the chemistry of proteins and amino acids. The method of teaching employed during the experiment was the project-oriented approach where educators established the complete order of work teams, content of the lessons, and other guidelines that guided the learners' actions. Students were then given the liberty to raise questions while planning investigative activities to find answers to the questions. The science teacher wanted to know if this way would increase students' motivation and if the learners would learn significant content about the proteins and amino acids. Student during the experiments determined their own solutions to teacher-suggested which is a problem-based strategy. In addition, they developed their own ideas for proteins and amino acids related to what was being studied in class.

At the end of the experiment, even if it was revealed that the instructor and learners both experienced some difficulty adjusting to the students-centered approach, the researcher observed that students were more motivated to learn than when he taught the class through traditional approach (Greenwald, 2000). Today's learners cannot operate without framework and forced control. They also have limited or no obligation to learning. Therefore, student-centered methods of content delivery provide learners with a chance to manage their knowledge since they expect learners to take liability for their learning to also increase their motivations. This is done by being aggressively occupied in the process of learning rather than just getting information from a speech (Yuzhi, 2003).

\section{Student-Centered Affects Students' Social Skills}

Student-centered method is a representation of a change in instructive approach from completive-founded to collaborative-founded instruction as a way of addressing variety in the classroom. This approach has a positive effect on theoretical attainment and socio-emotional factors, enabling students to tackle the interpersonal demands, requirements and diversity of the twenty-first century. Critics of this particular approach argue that even though student-centered approach increases student performance when correctly implemented, it does not necessarily mean that all operationalizations of this approach are equally effective. Additionally, many of the researches carried out have practical limitations and therefore any distinctions realized could be as a consequence of practical errors rather than the instructional approach itself (Brown, 2008).

In addition, student-centered learning strategies usually create unique chances for learners to take on problem solving with assistance from other team members. These strategies are founded in the conviction that knowledge is most efficient when learners are aggressively involved in working cooperatively and distributing ideas so as to finish educational assignments (Bush \& Saye, 2000). There has also been an increased comprehension that schools should not just teach learners to turn out to be good pupils, but should also socialize them to becoming effective and successful citizens. Numerous distinct approaches have been recommended in the past to attain the desired status of residency education. However, student-centered strategies such as cooperative learning are different from other teaching strategies in that they provide a classroom surrounding where sensible social skills are the main focus. The authority of these particular learning strategies, therefore, comes from placing students in the core of the knowledge procedure as the key component in it (Hannafin \& Land, 2000). Everything within the instruction procedure should serve learners so as to encourage learning. 
In addition, Dowaliby and Schumer (n.d) experimented about the effects of teacher-centered versus student-centered approaches on students' feeling. They taught two classes; each class was either student centered or teacher centered. The result was students who learned through student-centered approach had results that were higher than the class who learned through teacher-centered method because of the lack of anxiety and tension.

Conventional teacher-centered techniques concentrate on the shift of information between passive learners and active teachers. It has been observed that students in today's learning institutions have great distinctions in terms of prior knowledge, achievements, thinking capabilities, and social skills. Teacher-focused approaches should not to be ignored, especially when they do not work effectively in specific cases. These methods are appropriate for the type of problem identified in that they tend to promote student performance in many subjects. At times, teachers decide to let students sit without help and struggle with solving academic problems (Manning, 2000). Such an effort is believed to assist learners recognize and comprehend the parts of the puzzle when contemplating their issues. Societal skills development is not a key interest of a teacher-focused method simply because nearly all learning behaviors are founded on personal effort. This also discourages interpersonal teamwork and interpersonal efforts.

Eventually, the findings contained within the numerous articles reviewed tend to relate to each other in the sense that they agree on the inclusion of learner-centered learning strategies. The influence of supportive knowledge plans and teacher-centered plans on learners' employment of public skills indicated that there is an encouraging influence of supportive learning supported by social capabilities, as opposed to the teacher-oriented method (Blake, 2007). Recent studies conducted on techniques in teaching science in a few schools tended to emphasize the value of using student-centered strategies rather than teacher-centered ones. Notably, the student-centered techniques are more effective compared to teacher-centered approaches in comparable learning surroundings with similar backgrounds and populations. The student-centered approaches have so far brought about numerous advantages such as supporting teachers to expand their teaching methods for the sake of their students learning. They have also provided learners with sufficient discursive space aimed at demonstrating their creativity while optimizing their learning results.

With regards to modern day technology, it is necessary to include technology in line with lecture training and classroom management. There is need to present adequate training chances in order to practice effective design of the curriculum with the incorporation of modern day technology aimed at providing learner-centered experience (Ernst \& Ernst, 2005). Notably, there has been proof that teaching in a constructivist and active learning surrounding is more valuable than conventional instruction in promoting academic attainment, developing higher level thinking capabilities, enhancing students' interest, and increasing theoretical understanding. Student-centered learning generally seeks to offer the framework and focus that allow students to take responsibility for the meta-cognitive and cognitive aspects of their learning. What is being implied through the literatures considered above is that the teacher activity of clarifying the topic, availing illustrations, or suggesting arguments for or against a certain perspective may limit the students' need to think (Ivey, 2011). If learners see the teacher's cognition as important for the progression of their own capabilities and knowledge, they are placed in a teacher-centered group of practices and experiences, making them teacher-dependent. Moreover, little engagement by the teacher and leaving learners to determine what and how to learn without any criteria to judge their development, is unproductive and substandard, making a mockery of formal, higher education as an organized and designed system.

\section{Metholodgy}

Over the past years, there have been numerous attempts to implement student-centered approaches particularly in classrooms. Here, learners are presented with new issues to investigate where they decide what information to gather and what procedures to adhere to. Learners are also given the chance to construct their own clarifications for what they see. Although learners make progress in making their discourse more scientific, the way of discussing what they have seen in the science classroom does not come easily and teachers are forced to intervene. This has in turn created a tension between a prearranged manner of conducting something and the learners' more natural day-to-day manner of doing it. It raises questions about what it means to make use of a student-centered approach instead of teacher-centered approach. It is, therefore, significant to examine the effectiveness of the student-centered approach to teaching science in higher education on students' performance, students' motivation and students' social skills.

\subsection{Purpose, Question, and Hypotheses}

The purpose of this study was to examine the effectiveness of student-centered approach to teaching science in higher education on students' performance, students' motivation and students' social skills. 


\subsubsection{Research Questions}

1. What are the positive effects of implementing student-centered approach to teaching science in higher education on students' performance?

2. What are the positive effects of implementing student-centered approach to teaching science in higher education on students' motivation?

3. What are the positive effects of implementing student-centered approach to teaching science in higher education on students' social skills?

\subsubsection{Hypotheses}

In order to understand the questions, this study will analyze the following hypotheses:

\section{The hypotheses of the first research question are:}

$\mathrm{H}_{0}=$ The null hypothesis was that implementing student-centered approach to teaching science in higher education has positive influences on students' performance.

$\mathrm{H}_{\mathrm{a}}=$ The alternative hypotheses was that implementing teacher-centered approach to teaching science in higher education has positive influences on students' performance.

\section{The hypotheses of the second research question are:}

$\mathrm{H}_{0}=$ The null hypothesis was that implementing student-centered approach to teaching science in higher education has positive influences on students' motivation.

$\mathrm{H}_{\mathrm{a}}=$ The alternative hypotheses was that implementing teacher-centered approach to teaching science in higher education has positive influences on students' motivation.

\section{The hypotheses of the third research question are:}

$\mathrm{H}_{0}=$ The null hypothesis was that implementing student-centered approach to teaching science in higher education has positive influences on students' social skills.

$\mathrm{H}_{\mathrm{a}}=$ The alternative hypotheses was that implementing teacher-centered approach to teaching science in higher education has positive influences on students' social skills.

\subsection{Research Design}

In term of the education research method, the research design was the quantitative method that is a non-experimental design. The causal-comparative research that was used sought to identify associations among variables and attempted to determine the positive effects of using student-centered approach versus teacher-centered approach to teaching science on students' performance, motivation, and social skills among groups of students.

The research design consisted of independent and dependent variables. The independent variable was student-centered instruction. The dependent variables were students' academic achievement, motivation, and social skills.

The quantitative data was gathered before, during, and after the academic term Fall 2016 (16-weeks).

\subsection{Participants and Sampling}

Students in the Curriculum and Instruction master's program at California State University, Fresno were the participants. . The population in this study was 22 students who were admitted to the single subject credential program. The participants registered in Methods and Materials in Middle School Science Teaching (CI 161). Then, a nonrandom sample of these populations was used by selecting all the students of the credential program who enrolled in Methods and Materials in Middle School Science Teaching. The instructors taught them through student-centered method. In the other words, this study used the Convenience Sampling procedure.

\subsection{Instrument}

Students' science achievement was measured by using the pre-test and a post-test achievement test that created by this researcher based on expectancy and goals of the course. The professor provided the validity and reliability of the test.

In term of motivation, this research used a questionnaire instrument, conducting a questionnaire to measure students' motivation towards science learning. This questionnaire used six factors of motivation: self-efficacy, active learning strategies, science learning value, performance goal, achievement goal, and learning environment stimulation on a 
Likert scale of 5. The questionnaire was created by Tuan, Chin, and Shieh (2005).

In order to analyze the levels of students' social skills, a survey was conducted at the end of the academic term to measure the influence of this approach on students' social skills. The survey included six factors on a Likert scale to express students' agreement on each factor. These factors focused on classroom skills, communication skills, adaptive skills with others, friendship skills, tolerant of harsh behavior, and cultural skills. Four psychological experts supported face-validity, construct-validity and the reliability of this instrument. The survey was created by Ebrahim (2010).

\subsection{Data Collection and Analysis}

\subsubsection{Data Collection}

After students enrolled in the Methods and Materials in Middle School Science Teaching CI 161 and before doing the study, the students and teacher were informed by the university project advisor that they would be a part of this study during the semester. Then, the dean provided each student with a consent form to participate in the research study. In addition, this researcher explained the student-centered approach which the professor would use to teach the course, and students were given the choice to participate. At the beginning of the term, I tested the participants by using a pretest achievement test to measure students' academic achievement. Then, they took class each week over the Fall term. During the term, students did weekly homework. In addition, social skills were determined by using the checklist observation to realize the influence of learner-based on students' social skills. At the end of the term, I tested students by using a posttest achievement test. In addition, students' social skills were determined by doing the survey. Also, the participants completed the social skills survey.

\subsubsection{Data Analysis}

The effects of the teaching method student-centered approach on students' science performance, motivation, and social skills were analyzed with T-test sand statistics using SPSS. This way of analysis helped to find the positive effects of student-centered approach on students' science performance, motivation, and social skills.

\subsection{Ethical Standards}

This study adheres to the Ethical Standards in Human Subjects Research of the American Psychological Association (Publication Manual of the American Psychological Association, 2010). Additionally, the project was reviewed and approved by the dean of the Kerman School at California State University, Fresno.

\section{Result}

This section includes the analysis of the pretest and posttest in order to measure the impact of implementing student-centered approach on students' achievement. In addition, this chapter presents the analysis of the questionnaires that were used to assess the impact of implementing student-centered approach on students' motivation and their social skills. Microsoft Excel and Statistical Analysis Software Package (SPSS Statistics) were used to collect and analyze the data, calculate the percentages for each question, and draw the charts.

\subsection{Science Achievement Results}

Originally, the sample of 22 students of the CI 161 class were given a pretest; after a period of 16 weeks, the students were given the posttest. The descriptive statistics (sample sizes, means, standard deviations) for the pretest and posttest results science achievement shows that the means are different (Table 1). The mean scores of the pre-test was 8.5 and the post-test was 12 .

Table 1. Descriptive statistics (sample sizes, means, and standard deviations) of the students' achievement

\begin{tabular}{lcrrrr}
\hline \multicolumn{7}{c}{ Descriptive Statistics } \\
\hline & $\mathrm{N}$ & \multicolumn{1}{c}{ Minimum } & \multicolumn{1}{c}{ Maximum } & \multicolumn{1}{c}{ Mean } & \multicolumn{2}{c}{ Std. Deviation } \\
\hline PRE-TEST & 22 & 6.0 & 12.0 & 8.500 & 1.4720 \\
\hline POST-TEST & 22 & 9.0 & 14.0 & 12.182 & 1.2960 \\
\hline Valid N (listwise) & 22 & & & & \\
\hline
\end{tabular}

In addition, the standard deviations are slightly different, and the posttest scores are higher than the mean score of the pre-test. Table 2 shows a significant increase in learning from pre-test to post-test by at least $30 \%$. 
Table 2. Descriptive statistics (percentages) of the students' achievement

\begin{tabular}{ccc}
\hline Grade & Pre-test & Post-test \\
\hline A & $0 \%$ & $41 \%$ \\
\hline B & $5 \%$ & $42 \%$ \\
\hline C & $14 \%$ & $13 \%$ \\
\hline D & $36 \%$ & $4 \%$ \\
\hline F & $45 \%$ & $0 \%$ \\
\hline
\end{tabular}

\subsection{Students' Motivation Towards Science Learning Results}

The results were based on the total points of student's SMTSL responses. Students-centered approach affects the six factors of motivation positively when:

1. The total score of the Self-efficacy items was equal or lower than 14 .

2. The total score of the active learning strategies items was equal or grater than 24 .

3. The total score of the science learning value items was equal or grater than 20 .

4. The total score of the performance goal items was equal or grater than 10 .

5. The total score of the achievement goal items was equal or grater than 24 .

6. The total score of the learning environment stimulation items was equal or grater than 24 .

The descriptive statistics (sample sizes, means, standard deviations, and percentages) for the social skills questioner (Table 3) and Figure 1 show that the $86 \%$ of the students had their total score of the self-efficacy items around 13. In addition, based on Table 3 and figure 2, the mean of the total score of the active learning strategies items was 26, 86\% of the students' total scores occurred within 24 and 40. Furthermore, according to Table 3 and Figure 3, the mean of the total score of science learning value items for $96 \%$ of the science students was 23 . As well, regarding to Table 3 and Figure 4, the mean of $73 \%$ of the students was 11 points of the total score of the performance goal items. In term of achievement goal, total scores in table 3 and figure 5 show that $64 \%$ of the class got 23 points. The mean of the last factor, which is learning environment stimulation, was 23 points.

Table 3. Descriptive statistics (sample sizes, means, and standard deviations) of the students' motivation

\begin{tabular}{|c|c|c|c|c|c|}
\hline \multicolumn{6}{|c|}{ Descriptive Statistics } \\
\hline & $\mathrm{N}$ & Minimum & Maximum & Mean & $\begin{array}{c}\text { Std. } \\
\text { Deviation }\end{array}$ \\
\hline Self efficacy Statements & 22 & 9.0 & 17.0 & 12.591 & 2.0391 \\
\hline Active learning strategies & 22 & 21.0 & 30.0 & 26.273 & 2.8315 \\
\hline Science learning value & 22 & 19.0 & 25.0 & 22.864 & 2.1447 \\
\hline Performance goal & 22 & 4.0 & 16.0 & 10.727 & 2.7634 \\
\hline Achievement goal & 22 & 16.0 & 30.0 & 22.909 & 4.1965 \\
\hline Learning environment stimulation & 22 & 18.0 & 30.0 & 23.045 & 3.2290 \\
\hline Valid N (listwise) & 22 & & & & \\
\hline
\end{tabular}




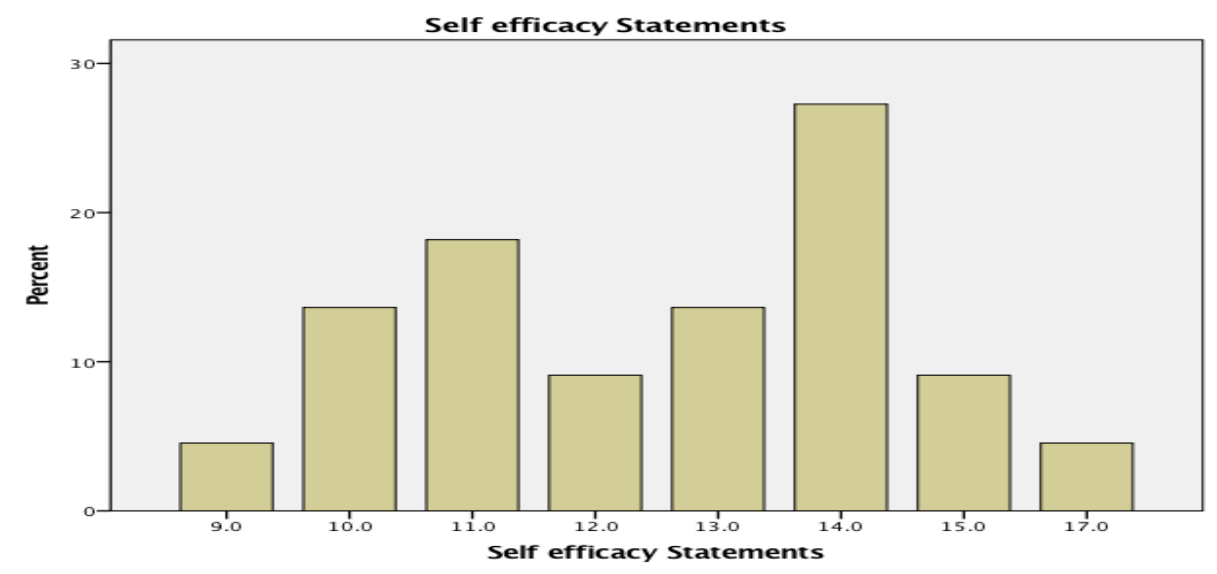

Figure 1. Frequency of self-efficacy

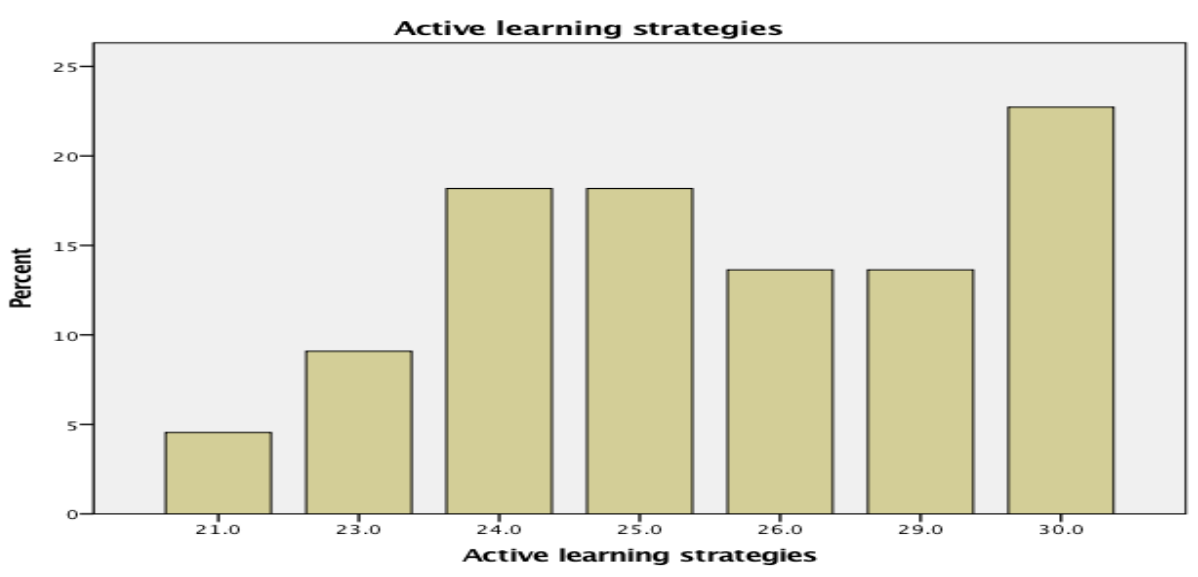

Figure 2. Frequency of active learning strategies

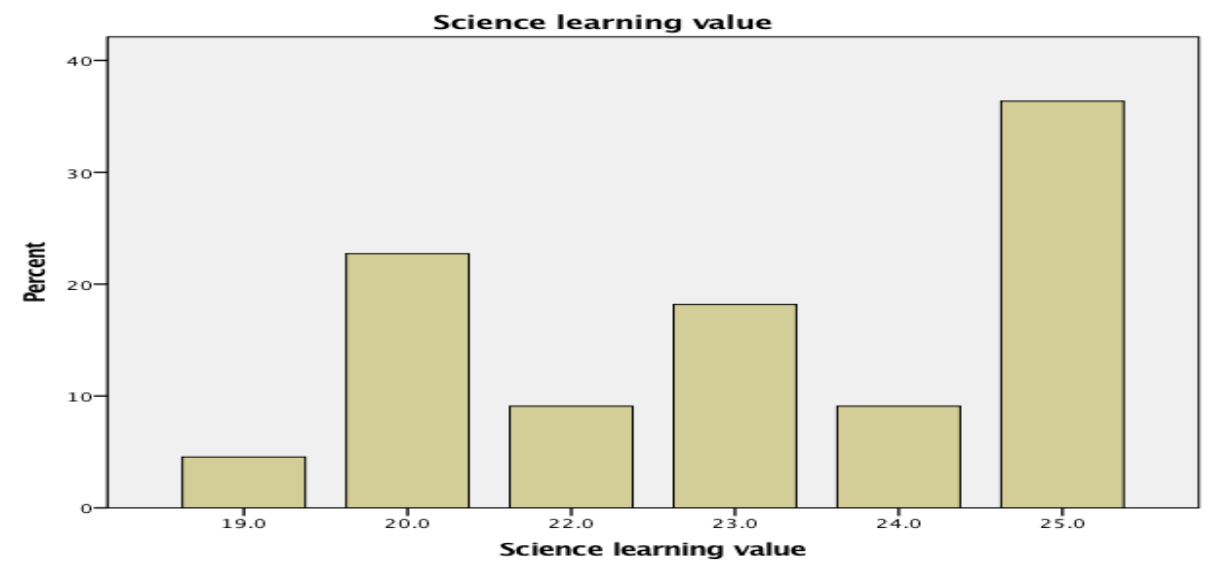

Figure 3. Frequency of Science learning 


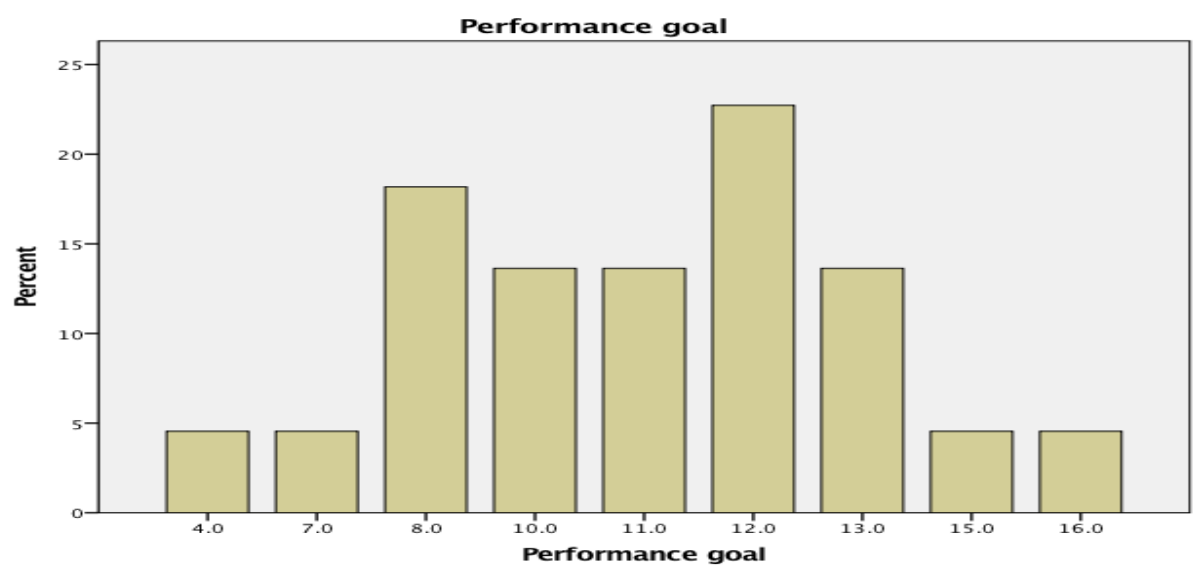

Figure 4. Frequency of Performance goal

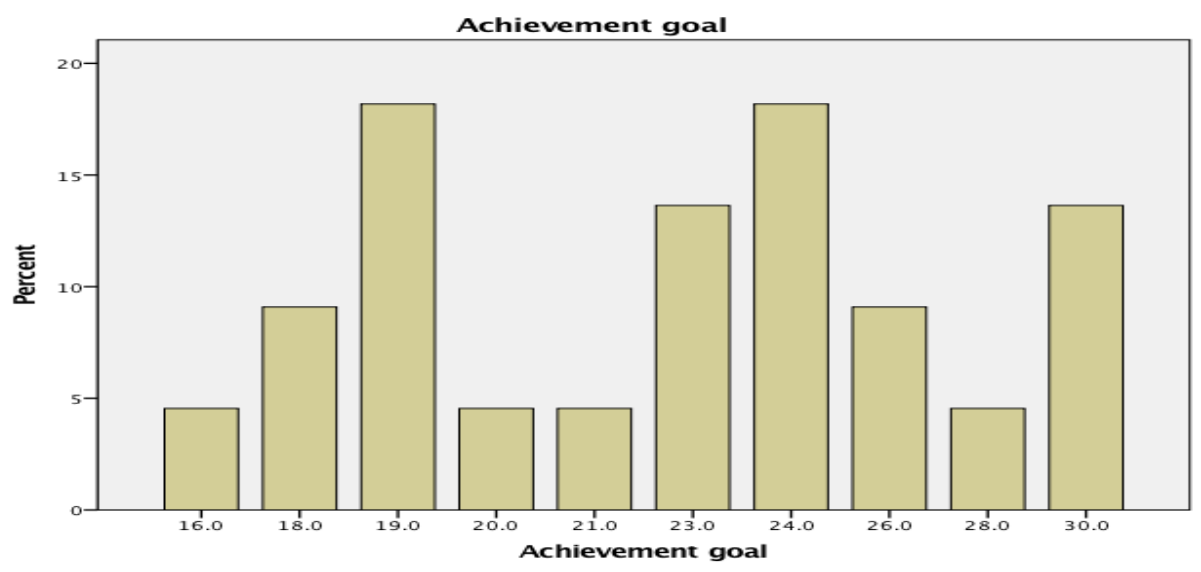

Figure 5. Frequency of Achievement goal

\subsection{Social Skills Results}

The results were based on the total score of the student's Social Skills questionnaire. Students-centered approach affects student's social skills positively when the total score of their response was equal or grater than 48 points. According to the descriptive statistics (sample sizes, means, and standard deviations) for the social skills questioner (Table 4) shows that the mean was $(\mu=48.72)$ that occurred within $95 \%$ confidence interval of the sample mean (probability $\geq 0.05$ ), which is between the lowest value and the greatest value [35,60]. In addition, Figure 6 shows that there were $60 \%$ of the science students who got more than 48 points on this survey.

Table 4. Descriptive statistics (sample sizes, means, and standard deviations) of the social skills questioner

Descriptive Statistics

\begin{tabular}{lcrrrr}
\hline & N & Minimum & Maximum & \multicolumn{1}{l}{ Mean } & \multicolumn{1}{c}{ Std. Deviation } \\
\hline Total score & 22 & 35.00 & 60.00 & 48.7273 & 6.37840 \\
\hline Valid N (listwise) & 22 & & & & \\
\hline
\end{tabular}




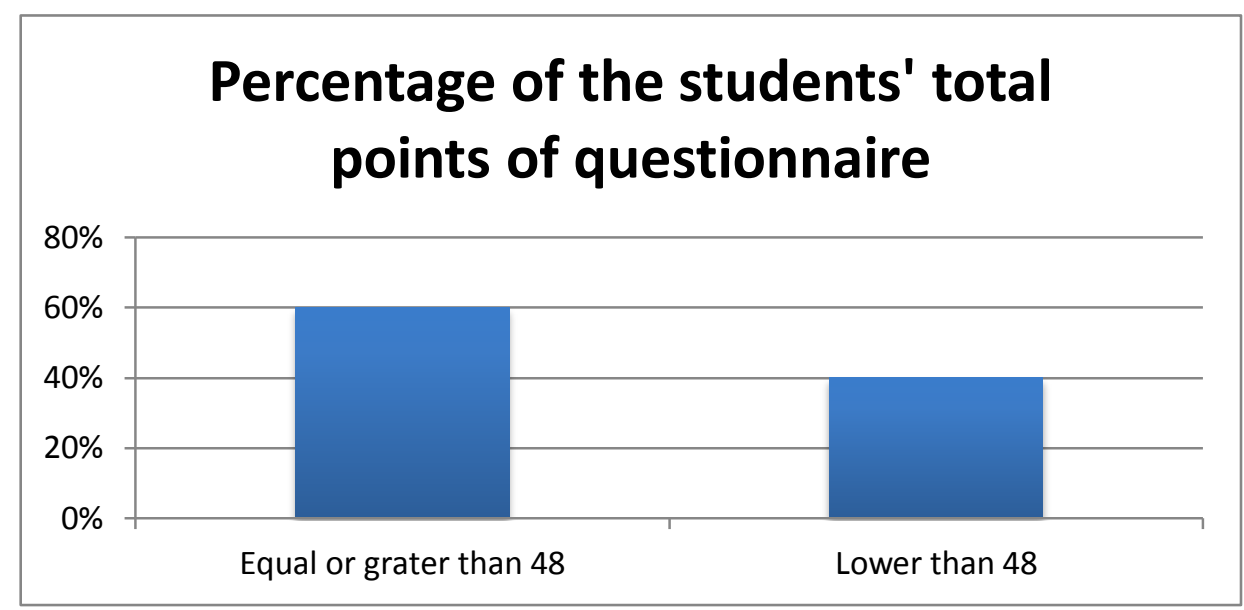

Figure 6. Percentages of the total score

\section{Conclusion}

\subsection{Discussion}

Students' Academic Achievement: The purpose of this study was to examine the effectiveness of student-centered approach to teaching science in higher education on students' performance, students' motivation and students' social skills. By using Paired Samples T-test to measure the impact of implementing student-centered approach to teaching science on student's academic performance, this research found that the test scores were statistically different between the pre-test and the post-test. The results were influenced by implementing students-centered approach to teaching science. Figure 7 shows the difference between the means of pre-test and post-test for science students. In addition, this research computed that the overall average post-test score was $26.25 \%$ higher than pre-test; it was confirmed that the students' performance indeed scored statistically significantly higher after implementing student-centered approach. In addition, Table 5 shows that $\mathrm{t}_{\text {observed }}(-8.698)$ was lower than $\mathrm{t}_{\text {critical }}(1.9803)$ which means the null hypothesis is accepted. Also, since $\mathrm{p}>0.05$ (in fact $\mathrm{p}=2.098$ ), we accepted the null hypothesis which was implementing learner-centered approach to teaching science in higher education had positive influences on students' performance.

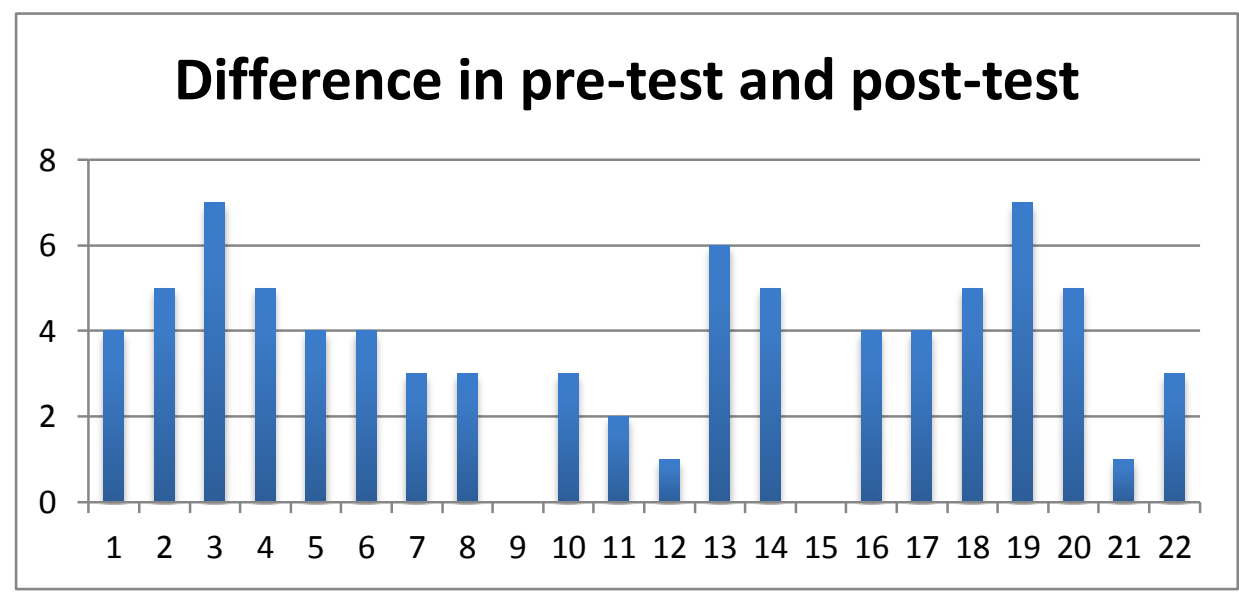

Figure 7. Difference in pretest and posttest 
Table 5. Paired Samples Test

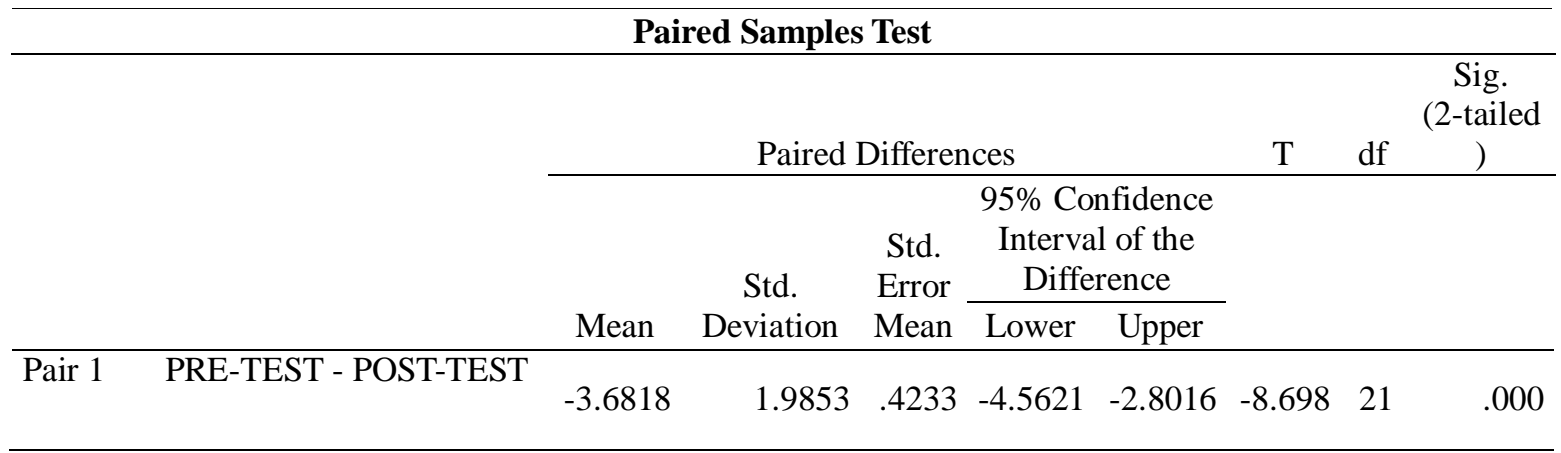

Students' Motivation Towards Science Learning: In term of learners' motivation, the null hypothesis was that implementing student-centered approach to teaching science in higher education has positive influences on students' motivation was proven. By looking to Table 3, we found that students-centered approach increased self-efficacy and active learning strategies of $86 \%$ of the class. Self-efficacy and active learning strategies will help students to believe in their own ability to perform well in science learning tasks. Also, this finding shows that students take an active role in using a variety of strategies to construct new knowledge based on their previous understanding. Based on the results of the survey, the student-centered learning approach has a positive impact on developing the science skills of students. Figure 3 shows that this class lets all the students to acquire problem-solving competency, experience the inquiry activity, stimulate their own thinking, and find the relevance of science with daily life. According to Figures 4 and 5, for more than half of the class, students-centered increased their performance goal and achievement goal. In this term student's goals in science learning were to compete with other students and get attention from the teacher. In addition, students feel satisfaction as they increase their competence and achievement during science learning. Learning environment surrounding students, such as curriculum, teachers' teaching, and pupil interaction influenced students' motivation positively in science learning.

Students' Social Skills: Based on the total score of student's Social Skills questionnaire on Figure 6, 60\% of the students earned equal or grater than 48 points. In this case, the null hypothesis was proven that students-centered approach affects student's social skills positively. This finding suggests that learning is more effective when students are actively involved in sharing ideas and working cooperatively with other students to complete academic tasks. In addition, when students participate actively in productive learning processes, they are able to negotiate shared meaning and construct meaningful understanding, which is not always possible in a teacher-directed approach. Also, learner-centered approach promotes a sense of individual responsibility and a love of challenge in the student, thereby increasing motivation for learning. This is what appears to have happened in these cooperative learning groups.

\subsection{Limitation}

Although this research was carefully prepared, it still has limitations. There were a number of limitations to be considered and discussed. First of all, the sample size was quite small $(\mathrm{n}=22)$. It is hard to generalize the results based on the small size of sample. If I do the same research I will enlarge the number of sample to 100 participants. In addition, the research was conducted in one semester, which has lasted for 16 weeks. This period was not enough for the researcher to observe all of the students' performance in their class. It would be better if it was done in a longer time.

\subsection{Conclusion}

The aim of this research was to find out answers to the questions included in this research: what are the benefits of learner-centered approach to teaching science in higher education; what impact does a teacher have in the learner-centered method; how does student-centered approach impact on the performance of a student; how does learner-centered approach influence the motivation of a student; how does student-centered approach impact on the social skills of a student?

From the numerous experiments conducted with respect to student-centered learning approaches, it was observed that the group with problem-founded learning representation was more triumphant than the groups to which conventional teaching techniques were applied. 
This is to say that active learning methods are actually more successful compared to traditional methods. Problem-based learning is determined by group collaboration and group cohesion similar to cooperative learning strategies. Learning through honest inquiry takes time and educators need the liberty and time to become counselors of opinion rather than providers of knowledge. That is why it is crucial that in an effort to hold learners, educators and school officials accountable for higher standards, educational authorities not opt to an over-standardizing of the syllabus. This tends to produce a list of learning results that are easily gauged but that cause people to lose focus of other significant educational goals. Care needs to be taken in order to identify critical ideas for students to learn so that their understanding of subjects is as rich as possible. Other goals of teaching are determined by a foundation of theoretical knowledge. Those encouraging and persuading educators to shift in the entire spectrum of teaching and implement the cooperative learning methods in order to improve the educational system.

\section{References}

Akınoğlu, O., \& Tandoğan, R. Ö. (2007). The Effects of Problem-Based Active Learning in Science Education on Students' Academic Achievement, Attitude and Concept Learning. Eurasia Journal Of Mathematics, Science \& Technology Education, 3(1), 71-81.

Asoodeh, M. H., Asoodeh, M. B., \& Zarepour, M. (2012). The impact of student-centered learning on academic achievement and social skills. Procedia-Social and Behavioral Sciences, 46, 560-564.

Blake, J. (2007). The crucial role of student affairs professionals in the learning process. New Directions for Student Services, 117, 65-72.

Blumberg, P. (2009). Developing learner-centered teaching: A practical guide for faculty. San Francisco: Jossey-Bass.

Brown, J. K. (2008). Student-centered instruction: Involving students in their own education. Music Educators Journal, 94(5), 30-35.

Brush, T., \& Saye, J. (2000). Implementation and evaluation of a student-centered learning unit: A case study. Educational Technology Research and Development, 48(3), 79-100.

Davis, T. C., \& Lu', H. (2015). Student and Instructor-Centered Approaches to Teaching Precalculus. Primus, 25(6), 495-506.

Dowaliby, F., \& Schumer, H. (1973). Teacher-centered versus student-centered mode of college classroom instruction as related to manifest anxiety. Journal of Educational Psychology, 64(2), 125-132.

Ebrahim, A. (2012). The effect of cooperative learning strategies on elementary students'science achievement and social skills in Kuwait. International Journal of Science and Mathematics Education, 10(2), 293-314.

Ernst, H. R., \& Ernst, T. L. (2005). The promise and pitfalls of differentiated instruction for undergraduate political science courses: Student and instructor impressions of an unconventional teaching strategy. Journal of Political Science Education, 1, 39-59.

Greenwald, N. L. (2000). Learning from problems. The Science Teacher, 67(4), 28-32.

Hannafin, M., \& Land, S.M. (2000). Technology and student-centered learning in higher education: Issues and practices. Journal of Computing in Higher Education, 72(1), 3-30.

Ivey, G. (2011). Opening up the conversation on literacy, college, and career. Journal of Adolescent \& Adult Literacy, 55(2), 96-99.

Kennedy, R. (2009). The power of in-class debates. Active Learning in Higher Education, 10(3), 225-236.

Lord, T. (2001). 101 reasons for using cooperative learning in biology teaching. The American Biology Teacher, 63(1), 30-38.

Manning, M. L. (2000). Child-centered middle schools: A position paper. Childhood Education, 76(3), 154-159.

McFarlane, D. A. (2010). Teaching unmotivated and under-motivated college students: Problems, challenges, and considerations. College Quarterly, 13(3), 1-5.

Painter, D. D. (2009). Providing differentiated learning experiences through multigenre projects. Intervention in School and Clinic, 44(5), 288-293.

Sharkey, S., \& Weimer, M. (2016). Learner-Centered Teaching: Five Key Changes to Practice. Teaching Sociology, $31(2), 251$. 
Slunt, K. M., \& Giancarlo, L. C. (2004). Student-centered learning: A comparison of two different methods of instruction. Journal of Chemistry Education, 81(7), 985-988.

Tobin, K. (1993). Applications of qualitative and quantitative data in interpretive research. In International Conference on Interpretive Research in Science Education, Taipei, Republic of China.

Tuan*, H. L., Chin, C. C., \& Shieh, S. H. (2005). The development of a questionnaire to measure students' motivation towards science learning. International Journal of Science Education, 27(6), 639-654.

Tulbure, C. (2011). Differentiating instruction upon learning styles in higher education: A controversial issue. Bulletin of the Transilvania University of Brasov, 53(4), 79-84.

Weimar, M. (2016). Learner-Centered Teaching: Five Key Changes to Practice. Retrieved 7 February 2016.

Yuzhi, W. (2003). Using problem-based learning and teaching analytical chemistry. The China Papers, 28-33.

\section{Appendices}

Appendix A: Pre-Test

Dear student,

I am Iman Alqahtani, MA in Education option Curriculum and Instruction. I am working on my project for class CI 298A; my advisor is Dr. Susan Schlievert, Professor, Department of Curriculum and Instruction (CI). In my project, I am exploring the impacts of implementing learner-centered approach to teaching science in higher education. I value your honest responses.

The test should take approximately 10 minutes to complete. Your responses are completely ANONYMOUS.

Your ID:

Your Name:

1- Curriculum based on inquiry shouldn't be set up to ask tons of questions of the students, but more so to get the students to ask the right questions.
A. True
B. False
The correct answer is

2- The National Research Council's (NRC) Framework describes a vision of what it means to be proficient in science; it rests on a view of science as both a body of knowledge and an evidence-based, model and theory building enterprise that continually extends, refines, and revises knowledge. It presents three dimensions that will be combined to form each standard: (which one is not correct)
A. Science and engineering practices
B. Disciplinary Core Ideas
C. Science Inquiry
D. Crosscutting Concepts

3- NGSS Stands for:
A. New Generation Science Statements
B. Next Generation Science Statements
C. New Generation Science Standards
D. Next Generation Science Standards

The correct answer is ........

4- What is the "Framework"?
A. A Framework for Understanding Science
B. A Framework for Science Teaching
C. A Framework for Science Professional Development
D. A Framework for K-12 Science Education

The correct answer is ........

5- SEP's are :
A. Science and Engineering Practices
B. Science and Engineering Principles
C. Science and Engineering Premises

The correct answer is ........ 
D. Space and Engineering Practices

6- DCI's are:
A. Dedicated Concept Ideas
B. Decision Concept Icons
C. Disciplinary Core Ideas
D. Disciplinary Concept Ideas

The correct answer is

7- The big idea of NGSS is this: focus on a limited number of core science ideas over a long time period (Kindergarten-12th grade) to create a foundation for students to better understand the world we live in.
A. True
B. False
The correct answer is

8- How misconceptions occur (which one is NOT TRUE)
A. Incomplete or insufficient experiences
B. Faulty explanations
C. Linked to intuitive ideas
D. Linked to life

The correct answer is ........

9- Misconceptions can be referred to as a preconceived notion or a conceptual misunderstanding. These are cases in which something a person knows and believes does not match what is known to be scientifically incorrect.
A. True
B. False

The correct answer is

$10-$ is occurs as a result of development of a child's

logical capabilities, and involves the "domain-general modification of cognitive structures that affect the knowledge acquisition process"
A. Misconception
B. Conceptual change
C. Framework for 21st Century Learning
D. Common Core State Standards

The correct answer is ........

11- The BSCS 5E Instructional Model consists of the following phases:

A. engagement, exploration, explanation, elaboration, and evaluation.

B. engagement, exploration, explanation, examination, and evaluation.

C. engagement, exploration, estimate, examination, and evaluation.

The correct answer is

D. engagement, engineer, explanation, elaboration, and evaluation.

12- In a confirmation inquiry the teacher has a greater degree of control by supporting and directing the students during the phases of the inquiry. These phases are: Question/hypotheses, Operationalization, and partly on Data collection. The students then need to perform the rest of the phases, data collection, interpretation and communication. However, in the structured inquiry teachers guidance can be spread in most of the other phases by assisting students in certain sub- tasks.
A. True
B. False
The correct answer is

13- In a guided inquiry, the teacher is in charge of the first phase by deciding on the topic and creating the hypotheses and the students is taking control of all the other phases. However, the teacher can offer his/hers guidance throughout the process when necessary by assisting the students either on a phase level or on a sub-phase level.
A. True
B. False

14- There are 3 Levels of inquiry (which one is NOT TRUE)
A. Structured inquiry
B. Student-initiated inquiry
C. Guided inquiry
D. Close inquiry

The correct answer is

The correct answer is 


\section{Appendix B: Post-Test}

Dear student,

I am Iman Alqahtani, MA in Education option Curriculum and Instruction. I am working on my project for class CI 298A; my advisor is Dr. Susan Schlievert, Professor, Department of Curriculum and Instruction (CI). In my project, I am exploring the impacts of implementing learner-centered approach to teaching science in higher education. I value your honest responses.

The test should take approximately 10 minutes to complete. Your responses are completely ANONYMOUS.

Your ID:

Your Name:.

1- Curriculum based on inquiry shouldn't be set up to ask tons of questions of the students, but more so to get the students to ask the right questions.

- True

- False

The correct answer is

2- Science Inquiry is the National Research Council's (NRC) Framework describes a vision of what it means to be proficient in science; it rests on a view of science as both a body of knowledge and an evidence-based, model and theory building enterprise that continually extends, refines, and revises knowledge. It presents three dimensions that will be combined to form each standard: (which one is not correct)

- True

- False

3- NGSS Stands for:

- New Generation Science Statements

- Next Generation Science Statements

- New Generation Science Standards

- Next Generation Science Standards

4- "Framework" is A Framework for Science Teaching?

- True

- False

5- SEP's are :

- Science and Engineering Practices

- Science and Engineering Principles

- Science and Engineering Premises

- Space and Engineering Practices

6- DCI's are Disciplinary Core Ideas:

- True

- False

7- The big idea of NGSS is this: focus on a limited number of core

science ideas over a long time period (Kindergarten-12th grade) to create a foundation for students to better understand the world we live in.

- True

- False

The correct answer is

8- How misconceptions occur (which one is NOT TRUE)

- Incomplete or insufficient experiences

- Faulty explanations

- $\quad$ Linked to intuitive ideas

The correct answer is

- Linked to life

9- Misconceptions can be referred to as a preconceived notion or a conceptual misunderstanding. These are cases in which something a person knows and believes does not match what is known to be scientifically incorrect.

- True 


\section{- False}

10- Misconception is occurs as a result of development of a child's logical capabilities, and involves the "domain-general modification of cognitive structures that affect the knowledge acquisition process"

- True

- False
The correct answer is

11- The BSCS 5E Instructional Model consists engagement, engineer, explanation, elaboration, and evaluation:

- True

- False.

The correct answer is
12- In a confirmation inquiry the teacher has a greater degree of control by supporting and directing the students during the phases of the inquiry. These phases are: Question/hypotheses, Operationalization, and partly on Data collection. The students then need to perform the rest of the phases, data collection, interpretation and communication. However, in the structured inquiry teachers guidance can be spread in most of the other phases by assisting students in certain sub- tasks.

$\begin{array}{ll}\text { - } & \text { True } \\ \text { - } & \text { False }\end{array}$

The correct answer is ........

13- In a guided inquiry, the teacher is in charge of the first phase by deciding on the topic and creating the hypotheses and the students is taking control of all the other phases. However, the teacher can offer his/hers guidance throughout the process when necessary by assisting the students either on a phase level or on a sub-phase level.

- True

- False

14- There are 3 Levels of inquiry is Close inquiry one of them:

The correct answer is ........

- True

- False 


\section{Appendix C: Social Skills Survey}

Social Skills Survey

Think about your science classes for the past few weeks and respond to the following statements as honestly as possible. The data collected by this survey will remain confidential and will not be provided to the science teacher or others, except in a summary fashion.

\begin{tabular}{|c|c|c|c|c|c|}
\hline Statements & $\begin{array}{l}\text { Strongly } \\
\text { Disagree }\end{array}$ & Disagree & Neutral & Agree & $\begin{array}{l}\text { Strongly } \\
\text { Agree }\end{array}$ \\
\hline \multicolumn{6}{|l|}{$\begin{array}{l}\text { I was able to help my friends who needed help } \\
\text { during the science class. }\end{array}$} \\
\hline \multicolumn{6}{|l|}{$\begin{array}{l}\text { I was able to work with my friends together to } \\
\text { answer questions or to solve problems. }\end{array}$} \\
\hline \multicolumn{6}{|l|}{$\begin{array}{l}\text { I learned how to choose freely the best choice to } \\
\text { solve a problem. }\end{array}$} \\
\hline \multicolumn{6}{|l|}{$\begin{array}{l}\text { In science class, I could discuss science with my } \\
\text { friends. }\end{array}$} \\
\hline \multicolumn{6}{|l|}{$\begin{array}{l}\text { In science class, I usually cared about my friends' } \\
\text { understanding. }\end{array}$} \\
\hline \multicolumn{6}{|l|}{ I learned in science class how to make friendships. } \\
\hline \multicolumn{6}{|l|}{$\begin{array}{l}\text { I learned in science class how to work with others } \\
\text { to solve problems or answer questions. }\end{array}$} \\
\hline \multicolumn{6}{|l|}{$\begin{array}{l}\text { I did not like to work in groups because my friends } \\
\text { in the group were slow to catch on. }\end{array}$} \\
\hline \multicolumn{6}{|l|}{$\begin{array}{l}\text { I did not like to work in groups because my friends } \\
\text { in the group were impatient with me. }\end{array}$} \\
\hline \multicolumn{6}{|l|}{$\begin{array}{l}\text { I did not like to work in groups because my friends } \\
\text { in the group were playing while I was working } \\
\text { on answering questions. }\end{array}$} \\
\hline \multicolumn{6}{|l|}{$\begin{array}{l}\text { I did not like to work in groups because it took too } \\
\text { much time from me to teach my friends the correct } \\
\text { answers. }\end{array}$} \\
\hline $\begin{array}{l}\text { I did not like to work in groups because my } \\
\text { friends in the group would not allow me to talk } \\
\text { when I had a different way to solve a problem. }\end{array}$ & & & & & \\
\hline
\end{tabular}

\section{Appendix D: Motivation Survey}

This questionnaire contains statements about your willingness in participating in this science class. You will be asked to express your agreement on each statement. There are no "right "or "wrong" answers. Your opinion is what is wanted. Think about how well each statement describes your willingness in participating in this class.

Draw a circle around

1. if the statement you strong disagree

2. if the statement you disagree

3. if the statement you have no opinion

4. if the statement you agree

5. if the statement you strong agree

Be sure to give an answer for all questions. If you change your mind about an answer, just cross it out and circle 
another.

Some statements in this questionnaire are fairly similar to other statements. Don't worry about this. Simply give your opinion about all statements.

\begin{tabular}{|c|c|c|c|c|c|}
\hline A. Self efficacy & $\begin{array}{l}\text { Strongly } \\
\text { disagree }\end{array}$ & Disagree & $\begin{array}{l}\text { No } \\
\text { opinion }\end{array}$ & Agree & $\begin{array}{l}\text { Strongly } \\
\text { agree }\end{array}$ \\
\hline $\begin{array}{l}\text { 1. Whether the science content is difficult or } \\
\text { easy, I am sure that I can understand it. }\end{array}$ & 1 & 2 & 3 & 4 & 5 \\
\hline $\begin{array}{l}\text { 2. I am not confident about understanding } \\
\text { difficult science concepts. }(-)\end{array}$ & 1 & 2 & 3 & 4 & 5 \\
\hline $\begin{array}{l}\text { 3. I am sure that I can do well on science } \\
\text { tests. }\end{array}$ & 1 & 2 & 3 & 4 & 5 \\
\hline $\begin{array}{l}\text { 4. No matter how much effort I put in, I } \\
\text { cannot learn science.(-) }\end{array}$ & 1 & 2 & 3 & 4 & 5 \\
\hline $\begin{array}{l}\text { 5. When science activities are too difficult, I } \\
\text { give up or only do the easy parts.(-) }\end{array}$ & 1 & 2 & 3 & 4 & 5 \\
\hline $\begin{array}{l}\text { 6. During science activities, I prefer to ask } \\
\text { other people for the answer rather than } \\
\text { think for myself. (-) }\end{array}$ & 1 & 2 & 3 & 4 & 5 \\
\hline $\begin{array}{l}\text { 7. When I find the science content difficult, I } \\
\text { do not try to learn it (-) }\end{array}$ & 1 & 2 & 3 & 4 & 5 \\
\hline
\end{tabular}


B. Active learning strategies

8. When learning new science concepts, I attempt to understand them.

9. When learning new science concepts, I connect them to my previous experiences.

10. When I do not understand a science concept, I find relevant resources that will help me.

11. When I do not understand a science concept, I would discuss with the teacher or other students to clarify my understanding.

12. During the learning processes, I attempt to make connections between the concepts that I learn.

13. When I make a mistake, I try to find out why.

14. When I meet science concepts that I do not understand, I still try to learn them.

15. When new science concepts that I have learned conflict with my previous understanding, I try to understand why.

C. Science Learning Value

16. I think that learning science is important because I can use it in my daily life.

17. I think that learning science is important because it stimulates my thinking.

18. In science, $I$ think that it is important to learn to solve problems.

19. In science, $I$ think it is important to participate in inquiry activities.

20. It is important to have the opportunity to satisfy my own curiosity when learning science.

D. Performance Goal

21. I participate in science courses to get a good grade. (-)

22. I participate in science courses to perform better than other students. (-)
Strong disagree

Disagree

1

1

1

1

2

No opinion

3

3

3

1

1

1

1

\section{Strong disagree}

1 Disagree

2

1

1

1

1

Strong disagree

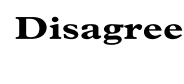

1

1

\section{No opinion}

3

3

3

3

3

No opinion

2

3

2
4

5

Agree

4

4

5

5

5

5

5

Agree Strong agree

5

5

5

5

$4 \quad 5$

Agree Strong agree

5

5

$\begin{array}{lll}3 & 4 & 5\end{array}$


23. I participate in science courses so that other students think that I'm smart.(-)

24. I participate in science courses so that the teacher pays attention to me.(-)

E. Achievement Goal

$\begin{array}{ccccc}1 & 2 & 3 & 4 & 5 \\ 1 & 2 & 3 & 4 & 5 \\ \begin{array}{c}\text { Strong } \\ \text { disagree }\end{array} & \text { Disagree } & \begin{array}{c}\text { No } \\ \text { opinion }\end{array} & \text { Agree } & \begin{array}{c}\text { Strong } \\ \text { agree }\end{array} \\ 1 & 2 & 3 & 4 & 5 \\ 1 & 2 & 3 & 4 & 5 \\ 1 & 2 & 3 & 4 & 5 \\ 1 & 2 & 3 & 4 & 5 \\ 1 & 2 & 3 & 4 & 5\end{array}$

25. During a science course, I feel most fulfilled when I attain a good score in a test.

26. I feel most fulfilled when I feel confident about the content in a science course.

27. During a science course, I feel most fulfilled when I am able to solve a difficult problem.

28. During a science course, I feel most fulfilled when the teacher accepts my ideas.

29. During a science course, I feel most fulfilled when other students accept my ideas.

F. Learning Environment Stimulation

30. I am willing to participate in this science course because the content is exciting and changeable.

31. I am willing to participate in this science Strong Disagree No Agree Strong disagree opinion agree course because the teacher uses a variety of teaching methods.

32. I am willing to participate in this science course because the teacher does not put a lot of pressure on me.

33. I am willing to participate in this science course because the teacher pays attention to me.

34. I am willing to participate in this science course because it is challenging.

35. I am willing to participate in this science course because the students are involved in discussions.

$\begin{array}{lllll}1 & 2 & 3 & 4 & 5 \\ 1 & 2 & 3 & 4 & 5 \\ 1 & 2 & 3 & 4 & 5 \\ 1 & 2 & 3 & 4 & 5 \\ 1 & 2 & 3 & 4 & 5 \\ 1 & 2 & 3 & 4 & 5\end{array}$

